\title{
Compliment Strategies Used by The Judges in Indonesian and American Idol 2019: A Cross-Cultural Pragmatics Study
}

\begin{tabular}{c} 
Muji Agustiyani \\
Airlangga University, Indonesia \\
Email Correspondence: muji.agustiyani-2019@fib.unair.ac.id \\
\hline
\end{tabular}

\begin{abstract}
Background:

This is a contrastive study that compares the investigation on the patterns of compliments strategies used by the judges in Indonesian Idol and American Idol 2019. This study aims at describing the compliment strategies addressed by the judges in two reality talent shows, that's a singing competition, and to reveal the differences of cultural values between the two societies.

Methodology:

The data is collected from the two YouTube accounts for the top three finalists' performance by utilizing the observation method with the note-taking technique. Ye's compliment strategies theory (1995) and Holmes' syntactic patterns of compliments (1995) are employed in analyzing the data.

Findings:

The result showed a significant difference between Indonesian and American judges in the way they give compliments. Indonesian judges prefer to use more explicit compliments while American judges prefer implicit compliments instead.

\section{Conclusion:}

It then revealed the contrastive cultural reflection of western people that is supposed to be 'more 'direct' in the way of speaking' (Wierzbicka, 2003). On the other hand, the finding exhibited contrast results from conventional perception upon Indonesian cultural predilection to 'indirectness' in the way of speaking.
\end{abstract}

Keywords: American Idol 2019; Compliment Strategies; Cross-cultural Pragmatics; Indonesian Idol 2019; The Judges.

DOI $\quad$ : http//dx.doi.org/10.24903/sj.v5i2.492

\begin{tabular}{l|l|l|}
\hline Received & $:$ & July 2020 \\
\hline Accepted & $:$ & September 2020 \\
\hline Published & $:$ & October 2020 \\
\hline Copyright Notice & $:$ & \begin{tabular}{l} 
Authors retain copyright and grant the journal right of first publication with the \\
work simultaneously licensed under a Creative Commons Attribution 4.0 \\
International License that allows others to share the work with an acknowledgment of \\
the work's authorship and initial publication in this journal. \\
\hline CC (i) O
\end{tabular} \\
\hline
\end{tabular}




\section{INTRODUCTION}

Language presents a substantial contribution to human interaction. To fulfill the desired need, people will use communication strategies when communicating with others. The strategies used may vary from culture to culture, which is most vividly seen in terms of interactional norms, i.e. 'directness' and 'indirectness'. The level of 'indirectness' itself also differs. This is due to the influence of several factors, such as ethnicity and culture, social status, gender, age, etc. "In many places where there are people of different cultural backgrounds in contact with each other, variations in 'indirectness' are reported" (Fought, 2006). Thus, the way people express and deliver messages, such as apology, request, complaint, invitation, and also compliment are diverse from one person to another.

A compliment is one way in daily communication that is adequate to create harmony and pleasures among speakers. The action of complimenting belongs to phatic communion, which possesses 'propitiatory' or emollient function (Boyle, 2000; Laver, 1975). Thus, a compliment has the power to soften one's feelings and demolish the silent gap between people. Holmes (1995) defined a compliment as follow:

A compliment is a speech act that explicitly or implicitly attributes credit to someone other than the speaker. Usually, the person addressed, for some 'good' (possession, characteristic, skill, etc.) which is positively valued by the speaker and the hearer (Holmes, 1995. p.117).

That means the content of a compliment is positive. It can convey pleasure to people who hear it. Such speech act is usually intended "to make others feel good" (Wierzbicka, 1987:201) where it has the potential of social function to "create or reinforce solidarity between the speaker and the addressee" (Wolfson \& Manes, 1980). Hood et al. (2020) consider complimenting as significant improvements in social interactions that can start and improve a great conversation and maintain businesses. However, compliments also own their darker side. Sometimes they can be labeled as 'flattery' and perceived as 'verbal harassment' or 'sarcastic'(see Holmes, 1995). In other words, there is a list behind the compliments given.

In some cases in societies, compliments can also be considered as 'face-threatening' where the element of envy is found (see Brown and Levinson, 1987; Holmes, 1995). The researcher found such this case happened in her life and the lives of many people around. For instance, when she complimented a bag, her male student was carrying to her English class, as in example 1.

A female teacher to her male student.

Teacher: Is that your bag?

Student: Yes. Why? 
Teacher: Woww, that's cute! I like your bag!

Student: (unexpectedly responded) Yah, how ya miss? I like this bag, too. I got this from barter with a friend from Baduy Badui tribe (one of tribes in Indonesia).

Teacher: Hmmm... Nice bag. (silently said "who wants to take your bag, dude!")

Student: But I promise you later to bring souvenirs from my hometown when I got back home.

This implied that her male student felt the teacher liked and wanted his bag, but he was reluctant to give it to her. As a result, he offered another alternative to keep him being polite while rejecting. A few weeks later, however, he eventually gave the bag to the teacher as a souvenir, and the teacher also gave him another item as a gift instead. This is an example of how a compliment can be somewhat face-threatening in which implies a perception of 'envy' or 'desire' element to have what the addressee possesses.

In our daily life interaction, we often hear compliments employed by people either sincerely or insincerely upon someone when he or she looks good, owns something new, does great works, possesses the remarkable skill and so on. What is salient to underline is that compliments received as compliments (experienced positively) only if they "implied approval of the addressee's accomplishments" (Wolfson, 1981:118). Especially in a reality talent show, compliments are often given when the judges commented on the finalists' performance.

A pioneering study of compliments has been conducted by some experts like Pomerantz (1978), Wolfson \& Manes (1980), Holmes (1995), and Ye (1995). Most research on compliments has paid particular attention to compliment response strategy either in a single language (Danziger, 2018; Pomerantz, 1978; Sartini, 2019) or comparison of two languages (R. Chen, 2010; Tang \& Zhang, 2009). This paper then will focus more on compliment strategies rather than how to respond (following Holmes 1995; Ye 1995; Wolfson \& Manes 1980). In the context of talent competition shows, similar research with the corresponding context has been conducted by some researchers mostly in a single language (Chen \& Rau 2015; Jamaluddin 2018; Mandalasari \& Hamzah 2018). Very few of them focus on strategies of compliments in two or more languages. Yet, this study is present to complete the gaps by focusing more on the strategy of compliment and carrying out a cross-cultural perspective. Lin's (2020) research is one of the most recent studies which discussed the strategies of compliment with more than one language along with criticisms strategies. The result showed that American, British, and Taiwanese judges offered more explicit than explicit compliments.

This study aims to describe the compliment strategies addressed by the judges in two reality talent shows from different countries - Indonesian Idol 2020 and American Idol 2019 
and to reveal the differences of its syntactic pattern and cultural values between the two societies. Ye's theory of compliment strategy (1995) is employed in analyzing the data. Furthermore, the core pattern of compliments is analyzed based on Holmes' syntactic patterns of compliments (1995).

As we have known, western people tend to hold cultural predilection to 'directness', so they prefer to speak 'to the point' of what they want to say (Wierzbicka, 2003). In this term, she mentioned English (White) and American (Black English) as the example in which characterized by a high degree of self-assertion, sincerity and spontaneity, compared to the other certain cultures. On the other hand, Indonesian cultural predilection, which is predominated by Javanese, mirrors 'indirectness' or 'indirection' as the main theme of their behavior (Geertz, 1976:244). They tend not to speak directly about what they mean and accentuate more the sense of feeling or rasa when speaking. As Suseno (1984) stated in his book entitled 'Javanese Ethics', it is very necessary to consider rasa in the speech act. $\mathrm{He}$ argued that indirect speech is considered as one of the Javanese politeness features to create harmony and respect. Finally, the final result of this research is also to determine whether the two cultural reflections works or even vice versa in term of 'complimenting'.

\subsection{Cross-Cultural Pragmatics}

Pragmatics is the study of what speakers mean, or 'speaker meaning' (Yule, 2006). It means that communication depends not only on recognizing the meaning of words but also recognizing the speakers' intended meaning by their utterances. However, the dimension in analyzing the speakers' meaning carries diversity due to different cultures and social groups. Wierzbicka (2003) subsequently proposed Cross-Cultural Pragmatics as the semantics of human interaction. In analyzing cross-cultural and intercultural issues, the concepts of 'mental schema' are necessary to be delved into. "When a schema (frame or script) is presumed shared, its content need not be mentioned explicitly in communication" (Spencer \& Oatey, 2008:78). When a schema of a language has been shared between communities or societies, what is wanted to be conveyed does not need to be explained explicitly. Thus, the participants in interaction should not rashly judge or get offended because people may have different schemata for similar things due to different culture.

\subsection{Compliment Strategies}

Ye (1995) divided the compliment strategy into three categories: (1) implicit compliment, (2) explicit compliment and (3) non-compliment.

\subsection{Patterns of Compliments}


Holmes (1995) stated that compliments are 'remarkably formulaic speech acts' which consists of a very small number of lexical items and a narrow range of syntactic patterns. Table 1 will help to summarize the syntactic patterns of compliments.

Table 1. Syntactic patterns of compliments and speaker gender

\begin{tabular}{|c|c|c|c|c|}
\hline \multicolumn{3}{|c|}{ Syntactic Formula* } & \multirow{2}{*}{$\frac{\text { Female \% }}{42.1}$} & \multirow{2}{*}{$\frac{\text { Male \% }}{40.0}$} \\
\hline 1. & $\begin{array}{l}\text { NP BE (LOOKING) (INT) ADJ } \\
\text {, e.g. That coat is really great }\end{array}$ & & & \\
\hline 2. & $\begin{array}{l}\text { I (INT) LIKE NP } \\
\text {, e.g. I simply love that skirt }\end{array}$ & & 17.8 & 13.1 \\
\hline 3. & $\begin{array}{l}\text { PRO BE (a) (INT) ADJ NP } \\
\text { e.g. That's a very nice coat }\end{array}$ & & 11.4 & 15.6 \\
\hline 4. & $\begin{array}{l}\text { What (a) (ADJ) NP! } \\
\text { e.g. What lovely children! }\end{array}$ & & 7.8 & 1.3 \\
\hline 5. & $\begin{array}{l}\text { (INT) ADJ (NP) } \\
\text { e.g. Really cool ear-rings }\end{array}$ & & 5.1 & 11.8 \\
\hline 6. & $\begin{array}{l}\text { Isn't NP ADJ! } \\
\text { e.g. Isn't this food wonderful! }\end{array}$ & & 1.5 & 0.6 \\
\hline 7. & All other syntactic formulae & & $\begin{array}{l}85.7 \\
14.3\end{array}$ & $\begin{array}{l}82.4 \\
17.6\end{array}$ \\
\hline & & Totals & 100.0 & 100.0 \\
\hline
\end{tabular}

Notes: *Following Manes \& Wolfson (1981) copula BE represents any copula verb; LIKE represents any verb of liking: e.g. love, enjoy, admire; ADJ represents any semantically positive adjective; and INT represents any boosting intensifier: e.g. really, very.

\section{METHODOLOGY}

The writer took the data from the Indonesian Idol YouTube channel account and Idols Global Channel account (for American Idol) and was limited only to the top three finalists' performance which consists of multiple rounds of eliminations. Indonesian Idol consists of three rounds; Road to Grand Final (top 3), Grand Final (top 2), and Result and reunion round (top 2). It has a total of 7 performance videos observed. Meanwhile, American Idol consists of two rounds; Top Three Final Round (6 videos) and Top Two Final Round (2 videos). It has a total of 8 performance videos observed.

The writer collected the data by utilizing the observation method with the note-taking technique that is transcribing the compliments given by the judges. The strategies used by the judges in giving compliments then would be examined and classified based on the categories of Ye's compliment strategy (1995). The core of compliment patterns would further be analyzed based on its syntactic pattern that is accounted for by Holmes (1995). The data is subsequently compared to Indonesian to discover the distinction between the two cultures.

\section{FINDINGS}

Based on the data description and analysis, all compliments strategies in the three episodes (from 7 videos), had been categorized into three forms that are an explicit compliment, implicit compliment, and non-compliment. 
Based on the result of data analysis, the researcher found there are three types of compliment strategy used by the judges. From Figure 1, it can be seen that the strategy that is mostly used is explicit compliments with its highest percentage, followed by implicit compliments and non-compliment.

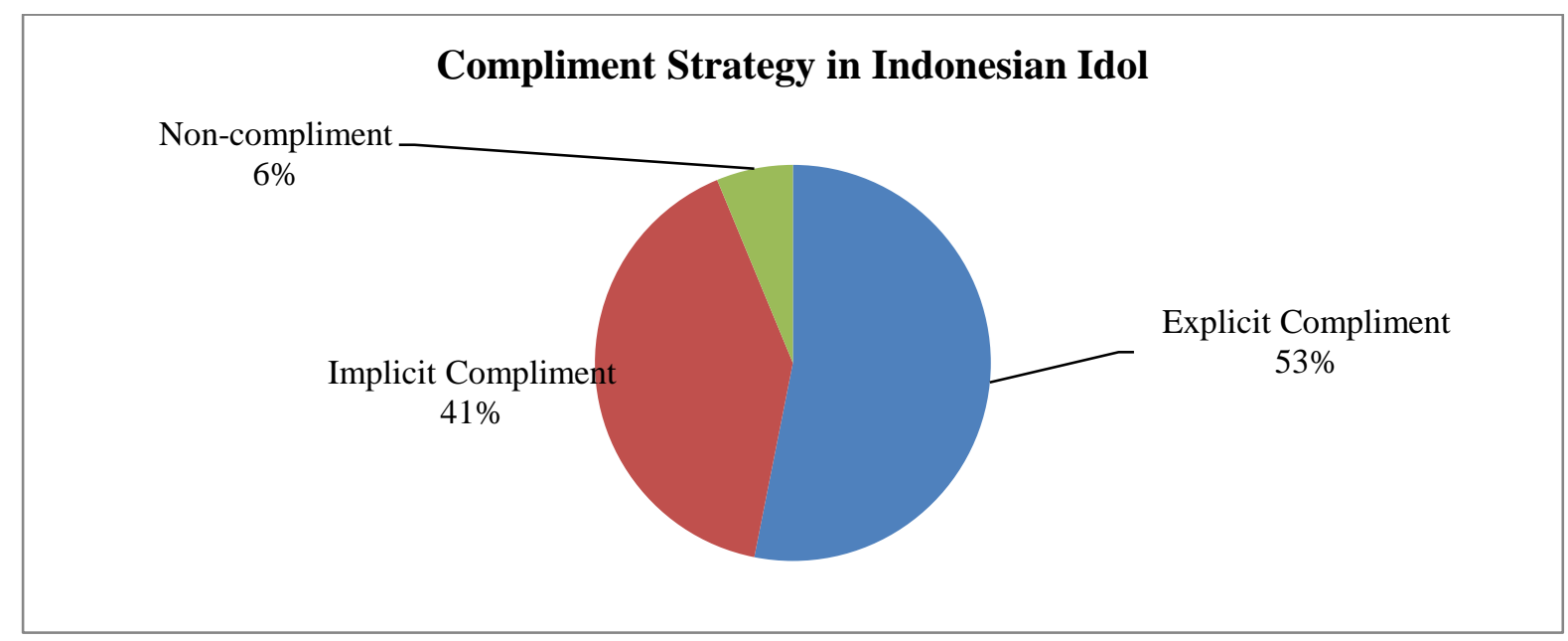

Figure 1. Compliment Strategy in Indonesian Idol

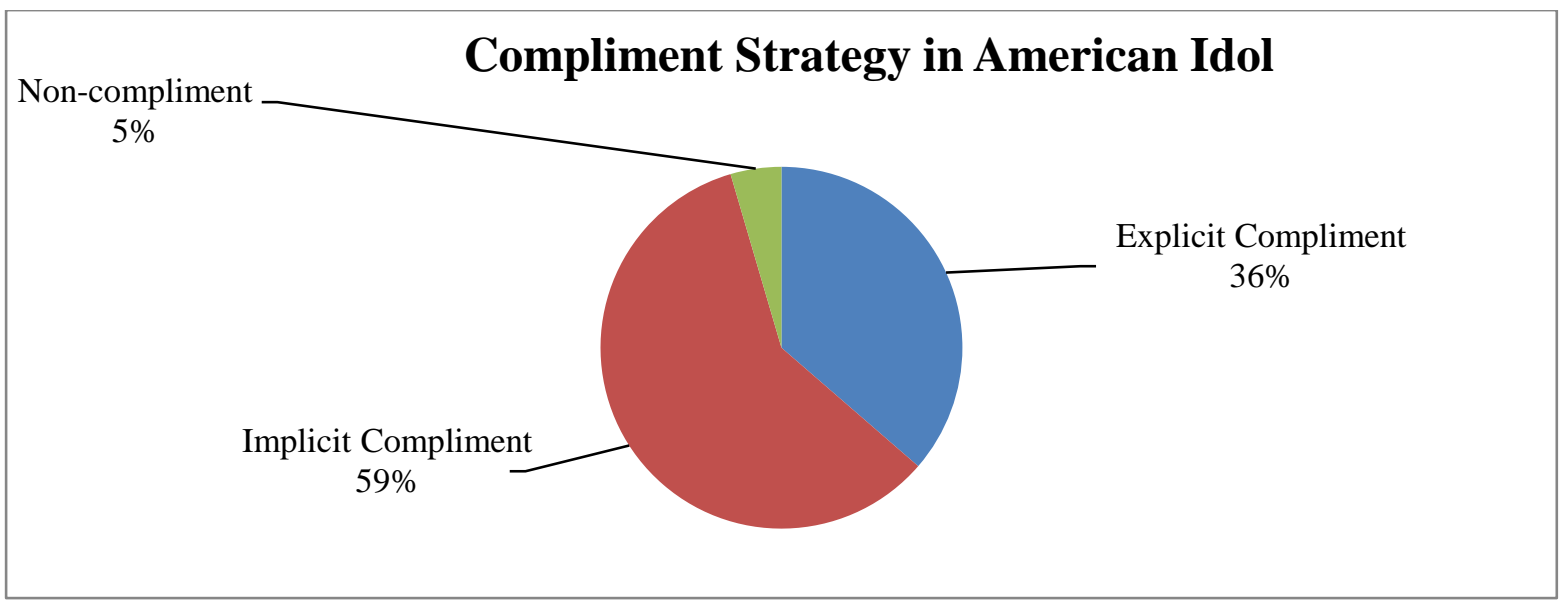

Figure 2. Compliment Strategy in American Idol

From Figure 2, it can be seen that the strategy that is mostly used is the implicit compliments with its highest percentage, followed by explicit compliments and noncompliment.

\section{DISCUSSION}

[Third Semifinals] - Indonesian Idol Channel

CONTEXT: Idol Indonesia 2019-2020 season 10. The addresses are the judges; Ari Lasso, Maia Estianti, Judika, Bunga Citra Lestari, and Anang Hermansyah. The addressees are the top 3 finalists; Lyodra Ginting, Tiara Andini, and Ziva Magnolya.

\subsection{Compliment Strategies}


The utterances uttered by Maia "Saya yakin kamu yang terbaik" and Lyodra, Juara 1" are direct compliment as she stated that Lyodra is likely to be the winner of Indonesian Idol season 10 .

Bunga's sentences "Jadi misalnya kamu punya single dilepas, itu pasti laku sih Tiara" and "Aku tidak sabar menanti penampilan kamu" tend to be implicit compliments since it has an implied meaning by saying that. Bunga tends to give assertion that Tiara's voice and performance are marvellous with its identifiable and strong character which are liked by many people, especially teenagers in Indonesia. She added again that she 'can't wait to see her performance' which means she fully hoped that Tiara would pass to the next round.

Ari's utterance "Lyodra, sekali lagi saya pengen semua bertepuk tangan untuk penampilan Lyodra barusan" refers to non-compliment because he didn't mean to give compliment to Lyodra but more likely to appreciate her performance by giving an instruction that's he wanted all the audiences to give applause on her performance.

\subsection{Patterns of Compliments.}

\subsubsection{Explicit Compliments.}

Judika's complement (on Lyodra) "Semua teknik kamu luar biasa" (Ind) or "All your techniques are awesome" (Eng) has the syntactic pattern:

$\begin{array}{ccc}\text { NP } & \text { BE }(\text { LOOKING) } & \text { (INT) ADJ } \\ \text { Poss.Adj } & \text { BE } & \text { (INT) ADJ } \\ \text { Your techniques } & \text { are } & \text { awesome }\end{array}$

Ari's personalized compliment "Jadi, aku bangga kamu ada disini" (Ind) or "I'm proud you are here" (Eng) has a slight different syntactic pattern from Holme's category which stated that LIKE represents any verb of liking; love, enjoy and admire. Those three verbs of liking could not be found in the data. Thus, the adjective 'PROUD' emerged inclined to closest in the sense of verb of liking; I (INT) LIKE NP.

$\begin{array}{cccc}\text { I } & \text { BE } & \text { (INT) LIKE } & \text { NP } \\ \text { I } & \text { BE } & \text { PROUD } & \text { Clause } \\ \text { I } & \text { am } & \text { proud } & \text { You are here }\end{array}$

Here, he applied 'personalized compliment form' by stressing its personal focus $I$ and you.

Maia's compliment (on Lyodra) "kamu yang terbaik" (Ind) or "You are the best" (Eng) has the syntactic pattern:

$\begin{array}{ccc}\text { PRO } & \text { BE (LOOKING) } & \text { (INT) ADJ } \\ \text { YOU } & \text { BE } & \text { (Superlative) ADJ } \\ \text { You } & \text { are } & \text { The best }\end{array}$

In this case, she applied 'personalized compliment form' by stressing its personal focus you. 
The syntactic pattern of compliment with this rhetorical pattern is not found in the data. This means that the judges do not really apply the compliments to stress its addressee or interaction-oriented characteristics on the force of the speech act.

Bunga's compliment (on Tiara) "Enak banget suaranya" (Ind) or "Very beautiful voice" (Eng) has the syntactic pattern:

\section{(INT)}

Very
ADJ beautiful
NP

Voice $(\mathrm{N})$

Here, the judge preferred to employ minimal pattern to reduce the syntactic pattern to its minimum elements.

The syntactic pattern of compliment with a tag-question is not found in the data. This may because the judges do not need approval or confirmation from the compliments they addressed to the finalists.

The compliment "Kamu memang udah calon diva di Indonesia" (Ind) or "You are already a diva candidate in Indonesia" (Eng) has the syntactic pattern:

$\begin{array}{cccc}\text { YOU } & \mathbf{V} & \text { (ADV) } & \text { NP } \\ \text { You } & \text { are }(\mathrm{BE}) & \text { already } & \text { A diva candidate }\end{array}$

The compliment "Kamu memang kamu memenangkan babak pertama" (Ind) or "You indeed won the first round" (Eng) has the same pattern, but with the adverb before the verb:

$\begin{array}{llll}\text { You } & \text { (ADV) } & \text { V } & \text { NP } \\ \text { You } & \text { indeed } & \text { won } & \text { The first round }\end{array}$

\subsubsection{Implicit Compliments.}

Judika's compliment (on Tiara) “... lagu ini kamu makan” (Ind) or "you eat this song” (Eng) embodies the reference for food since he presupposed the song as something to eat. This carries implicit meaning that Tiara succeeded in performing the song.

Bunga's compliment (on Tiara) "misalnya kamu punya single dilepas, itu pasti laku banget sih Tiara" (Ind) or "If you have a single released, it must sell well, Tiara" (Eng). The judges also sometimes assert future prediction to elucidate the possibility the finalists can carry and achieve with their skills and qualities.

Rossa's compliment (on Lyodra) "Kamu memang terlahir untuk menjadi seorang bintang" (Ind) or "You are born to be a star" (Eng) utilized a metaphor. It compares two unlike things, that is you (human) and star (thing). This implies that Lyodra has a bright future which shines like a star with her beautiful singing skill that people adore.

Anang's compliment (on Tiara) "Dia baru umur 18 tahun dan dia lahir benar dari perjuangan di daerah. Dia tidak menginjak Internasional." Or "She was only 18 years old and she was born from the struggle in a small area. She did not step on International track" 
contains the assertion that Tiara has a remarkable skill in spite of having lack of experiences, apart from her condition that is not supportive. This is supported by his previous statement in his comment "Ini sebuah gambaran bahwa Indonesia itu banyak talent muda yang luarbiasa" which means "This is a picture that Indonesia has many extraordinary young talents."

Only two data were found to be non-compliment. This is included in non-compliment because it does not tend to types of compliments. Nevertheless, it still carries a sense of compliment.

Ari’s compliment (on Lyodra) “Lydora, sekali lagi saya pengen semua bertepuk tangan untuk penampilan Lyodra barusan" or "Lydora, once again I want all to give applause for Lyodra's performance" has the pattern of imperative form, that is a command. Ari gave a command to the audience by asking them to give applause on Lyodra's performance. It indicates that Ari appreciated her performance since she performed incredibly awesome.

Maia's compliment (on Tiara) "Saya janji mau kasih kamu lagu boleh gak? Setelah habis dari Indonesian Idol, aku ketemu kamu ya" or "I promise to give you a song, may I? After this competition finishes (Indonesian Idol), I'll see you" offered a condition in which she promises to make a song for Tiara. This indicates that Tiara's performance and skill are very lovely and commercial, which will be liked by many people and the world of entertainment. This is supported by Maia's last statement in her comment, that is "Kamu sangat komersiil" or "you are very commercial."

\section{[Third Semifinals] - Idols Global Channel}

CONTEXT: American Idol 2019-2020 season 18. The addresses are the judges; Katty Perry, Lionel Richie, and Luke Bryan. The addressees are the top 3 finalists; Alejandro Aranda, Madison Vandenburg, and Laine Hardy.

\subsection{Compliment Strategies}

The judges' comments "It was love at first sound for you," "Great job, man," and "What a beautiful moment watching you, man" is categorized into explicit compliments. "It was love at first sound for you" shows that is the judge expresses his or her amazement at the beauty of Alejandro's voice and "What a beautiful moment watching you, man" clearly showed that the judge was enjoying the performance of him.

The sentence "some would say in the past American Idol, you know it's been a bit of a 'Karaoke' show. Not anymore when people like you come on" indicates implicit compliments which mean that the judge felt the different atmosphere which is more 
spectacular when he performs and sings on the stage, compared to the previous American Idol shows in the past. This can be supported by the next utterances added "You bring your original music. You bring artistry, and you make the stakes even higher, thank you."

Lionel's comment "Vote, vote, vote" indicates non-compliment since he didn't mean to give compliments but to appreciate Alejandro's performance by instructing the audience, that's to vote for him if they wanted to see him win the competition.

\subsection{Patterns of Compliments.}

\subsubsection{Explicit Compliments.}

The compliment 'You look like your so much fun' is addressed by Kattie on Laine's performance. This sentence has the syntactic pattern NP BE (LOKING) (INT) ADJ. In this case, Kattie applied a 'personalized compliment form' by stressing its focus you.

The sentence 'your range is just so impressive' has the pattern NP BE (LOOKING) (INT) ADJ. The compliment 'you are great' is genuinely concise but gives stress on direct compliment addressed to the finalists. The syntactic pattern is NP BE ADJ. This pattern of compliment embodies personalized form since it uses a personal focus 'you.'

The compliment 'We love you' and 'we love when we see a person like yourself shine' has a similar pattern that is I (INT) LIKE NP. However, the personal focus I am replaced by 'We' since it represents all three judges.

The use of intensifiers is also employed by the judges in their compliments giving. The sentence 'It's been so amazing to watch' contains the intensifier 'so' with the pattern PRO $B E(a)(I N T) A D J V P$.

Luke's comments on Alejandro's performance. What a beautiful moment watching you man has the core of compliment 'What a beautiful moment.' Luke used the rhetorical pattern What (a) (ADJ) NP!

Luke frequently uses the compliment 'Great Job' at the end of his comments on the three finalists. In this case, he prefers to use minimal pattern (INT) $A D J(N P)$ that is to reduce the syntactic pattern to its minimum elements.

The syntactic pattern of compliment with a tag-question is not found in the data. This may because the judges do not need approval or confirmation from the compliments they addressed to the finalists.

The pattern with 'superlative form' is found in the data. The sentence 'you have the best attitude I've ever checked the males across' signifies assertion on the addressee that he or she is the one with the quality. The syntactic pattern is PRO V (Superlative) ADJ (Clause). The 
pattern is almost similar to point number 3. In this case, the Intensifier is substituted into a Superlative form, and the Noun Phrase is substituted into a Clause instead.

\subsubsection{Implicit Compliment}

An idiomatic expression is a choice to illustrate the point of the compliment addressed. Katty used the expression 'you could hear a pin drop' to describe a situation of complete silence because all the entire spectators on the stage were very interested in Alejandro's performance. This is supported by her previous sentences 'While I was listening to that song and I think while everyone was listening to that song, they were truly listening.' This shows that everyone on the stage is paying attention and enjoying his performance. This is also added by the closing statement 'There is so much reverence and respect when you sing.

Luke's comment that begins with 'The whole time you were singing, Katie was yelling in my ear so loud' is very context-dependent in which in a concert or spectacle, this tends to be interpreted as the state of a person that is highly enthusiast and excited toward what he or she is watching and listening. This is supported by the next sentences Luke was trying to explain 'what's so exciting is your growth and you, finally we have been pushing you the whole time to dig in and show the world. Just how, just what kind of next-level voice you have.'

The preference for the figure of speech is often employed by the judges in giving the beautiful sound of compliments. Lionels's sentence (on Madison) 'you're amazing light' is a metaphor because it compares to unlike things - you (a person) and light. This implies that she can make things visible and stimulate people's sight to keep eyes on her. It denotes that she is shining bright and she is the person that is amazing to see.

Katty's comments (on Luke) 'Every week, your hair seems to be getting higher and higher. It's growing a little bit. You seem to be taking some pop star vitamins' indicates that she was trying to say that Luke seems to take some pop star vitamins for his hair. This Association between the ideas of pop stars and vitamins (for hair) is known as simile since it compares two things which are unalike using the words 'like', 'seem', or 'as.'

The judges also sometimes assert the future prediction to elucidate the possibility the finalists can carry and achieve with their skills and qualities, like in the closing sentence of Katty's comment 'if you apply yourself like you've applied yourself for the next five years every single week and don't get lazy, you're gonna be one of the biggest stars on this planet.' This sentence is also known as first conditionals.

Lionel's comment (on Alejandro) 'when you walked out on the stage, there's something about before they see you in four-five notes, you know it's you, my friend' is zero 
conditionals. It talks about facts and things that are true in which Alejandro does have a distinctive or unique voice character that when people (without seeing him) listen to him singing in four-five notes would directly know that he is the person. In other words, his voice is so identifiable.

The astonishment expression is usually started with some phrases like 'I can't believe' or 'I never thought.' Lionel's astonishment at Laine's growth is explained in his sentences 'I can't believe I was there saying "Laine, come on in join the competition!" and now form that point on not only did you join the competition, but you stole my look in the process now.' This indicates that Lionel compliment him because his growth and progress are much better than prior ones.

The judges sometimes give their compliments by giving a comparison between two things in which the latter is usually much better. Katty's statement (on Alejandro) 'some would say in the past American Idol, you know it's been a bit of a karaoke show. Not anymore when people like you come on,' indicates that he is the person who can bring a new taste and transform the previous ordinary show into an extraordinary one. This is added by the next sentences 'You bring your original music. You bring your artistry, and you make the stakes even higher.'

'We've thrown so many things at you that and watching you take them and then still stay who you are, play your music your way is so tough to do and don't ever change it that you're truly something to behold.' Lukes' comment on Alejandro indicates a situation that is opposed to one another, or contrasts belongs to antilogy. The sentences imply that apart from the difficult situation, he keeps on trying and making an effort, and that gives a very good result in the end. Luke was trying to compliment him on his good result by elucidating the contradict situation in the beginning.

Only two data were found to be non-compliment. This is included in non-compliment because it does not tend to types of compliments. Nevertheless, it still carries a sense of compliment.

Lionel's comment (on Alejandro) in the end 'Vote Vote Vote' has the pattern of imperative form. It indicates that Lionel appreciated his performance, and he did not want him to be eliminated.

Luke's comment (on Laine) 'what boots for those you break, those out of the closet?' has the pattern of question form. It indicates that Luke's fascinated by his look or appearance style, especially on his boots. 
To sum up, the distinctions between patterns of explicit and implicit compliments are that the first has a clear and detailed pattern, i.e. this can be broken down into its detailed parts of speech. Meanwhile, the latter is much longer in sentences and inclined to the outline since it utilizes several broad aspects; the use of figurative language, idioms, conditionals, contextdependent, comparison, astonishment expression, and antilogy. Besides, it needs interpreting further. Further, non-compliment is seen in the sentence form as a whole. It has two patterns found, that is, imperative and interrogative/question form.

This research revealed a significant difference between Indonesian and American judges in the way they give compliments. Indonesian judges prefer to use more explicit compliments; meanwhile, American judges prefer to use more implicit compliments. This was such an appealing phenomenon that so much different from the culture of western people which is generally labeled 'more explicit' in expressing their feelings and ideas. The comparison between the two talent shows can be seen in Figure 3.

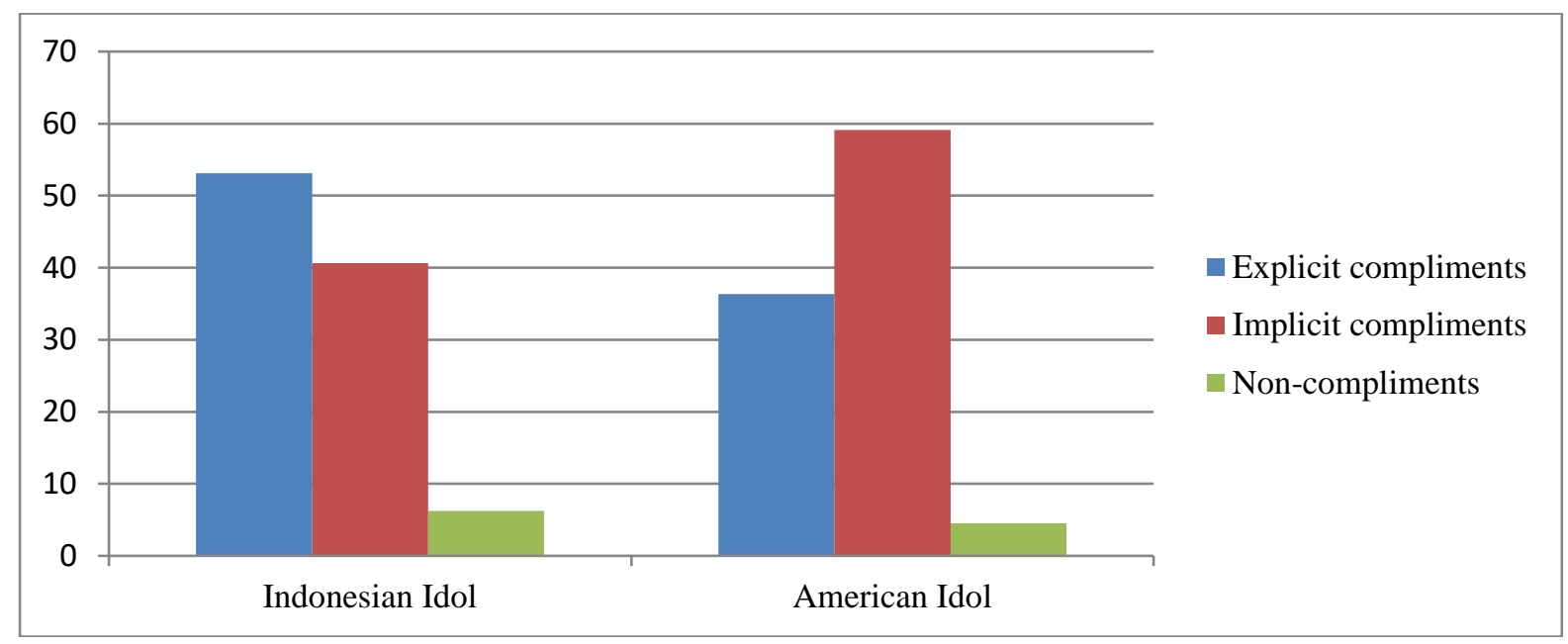

Figure 3. Compliment strategies used by the judges in Indonesian - American Idol 2019

\section{CONCLUSION}

Based on the conducted data analysis, the compliment strategies utilized by Indonesian judges are mainly explicit compliments, followed by implicit compliments and noncompliments. Whereas, American judges used mostly implicit compliments, followed by explicit compliments and non-compliments. From the investigation, it can be said that the way American judges gave compliments on the singing competition show is on the reverse with the cultural reflection of the western people that are supposed to be 'more 'direct' in the way of speaking' (Wierzbicka, 2003). On the other hand, the finding exhibited contrast results from conventional perception upon Indonesian people that are supposed to be 'indirect' in the way of speaking. This research, once again, was only limited to the scope of talent competition shows. 


\section{REFERENCES}

Boyle, R. (2000). "You've worked with Elizabeth Taylor!”: phatic functions and implicit. Applied Linguistics, 21(1), 26-46. https://doi.org/10.1093/applin/21.1.26

Brown, P., Levinson, S. C., \& Levinson, S. C. (1987). Politeness: Some universals in language usage. Cambridge University Press.

Chen, R. (2010). 2. Compliment and compliment response research: A cross-cultural survey. In A. Trosborg (Ed.), Pragmatics across Languages and Cultures (Issue March, pp. 79-102). DE GRUYTER MOUTON. https://doi.org/10.1515/9783110214444.1.79

Chen, Y., \& Rau, V. (2015). Compliments and criticisms given by judges on a singing competition series in Taiwan. Studies in English Language and Literature, 35, 1-19.

Danziger, R. (2018). Compliments and compliment responses in Israeli Hebrew: Hebrew university in Jerusalem students in interaction. Journal of Pragmatics, 124, 73-87. https://doi.org/10.1016/j.pragma.2017.12.004

Fought, C. (2006). Language and ethnicity. Cambridge University Press.

Geertz, C. (1976). The religion of Java. University of Chicago Press.

Holmes, J. (2013). Women, men and politeness. Routledge.

Hood, S. A., Olsen, A. E., Luczynski, K. C., \& Randle, F. A. (2020). Improving accepting and giving compliments with individuals with developmental disabilities. Journal of Applied Behavior Analysis, 53(2), 1013-1028. https://doi.org/10.1002/jaba.662

Jamaluddin, A. F., Wijayanto, A., \& Hikmat, M. H. (2018). Compliments and compliment responses used in America's Got Talent 2017 [Universitas Muhammadiyah Surakarta]. http://eprints.ums.ac.id/60803/

Kasper, G. (1995). Pragmatics of Chinese as native and target language (Vol. 5). Natl Foreign Lg Resource Ctr.

Laver, J. (1975). Communicative functions of phatic communion. In Organization of behavior in face-to-face interaction (pp. 215-238). Mouton The Hague.

Lin, C.-Y. (2020). Exploring judges' compliments and criticisms on American, British, and Taiwanese talent shows. Journal of Pragmatics, 160, 44-59. https://doi.org/10.1016/j.pragma.2020.02.008

Magnis-Suseno, F. (1984). Etika Jawa (Javanese ethics). Gramedia.

Mandalasari, M., \& Hamzah, H. (2018). Compliment strategy and topics based on gender differences by Indonesian Idol Judges 2018. E-Journal English Language and Literature, 7(4). http://ejournal.unp.ac.id/index.php/ell/article/view/101320

Manes, J., \& Wolfson, N. (1981). The compliment formula. In Conversational routine: Explorations in standardized communication situations and prepatterned speech (Vol. 96, pp. 115-132).

Pomerantz, A. (1978). Compliment responses. In Studies in the Organization of Conversational Interaction (pp. 79-112). Elsevier. https://doi.org/10.1016/B978-0-12623550-0.50010-0

Sartini, N. W. (2019). Compliment response strategy of Balinese women on social media: A Cyberpragmatic Study. Proceedings of the Fifth Prasasti International Seminar on Linguistics (PRASASTI 2019), 338, 373-376. https://doi.org/10.2991/prasasti19.2019.64

Spencer, O. H. (2008). Culturally speaking: Managing rapport through talk across cultures. Continuum.

Tang, C.-H., \& Zhang, G. Q. (2009). A contrastive study of compliment responses among 
Australian English and Mandarin Chinese speakers. Journal of Pragmatics, 41(2), 325345. https://doi.org/10.1016/j.pragma.2008.05.019

Wierzbicka, A. (1987). English speech act verbs: A semantic dictionary. Academic Pr.

Wierzbicka, A. (2003). Cross-cultural pragmatics. Walter de Gruyter Inc.

Wolfson, N. (1981). Compliments in cross-cultural perspective. TESOL Quarterly, 15(2), $117-124$.

Wolfson, N., \& Manes, J. (1980). The compliment as a social strategy. Paper in Linguistics, 13(3), 391-410. https://doi.org/10.1080/08351818009370503

Yule, G. (2006). The study of language: thoroughly revised and updated. Cambridge University Press. 